\title{
Evaluation of Precipitation and Evapotranspiration Obtained by Remote Sensing With Meteorological Stations in the State of Goiás
}

\author{
Victor Hugo Moraes ${ }^{1}$, Pedro Rogerio Giongo ${ }^{2}$, Bruno Henrique Tondato Arantes ${ }^{1}$, Estevam Matheus Costa $^{1}$, \\ Matheus Vinícius Abadia Ventura ${ }^{1}$, Thomas Jefferson Cavalcante ${ }^{1} \&$ Angelina Maria Marcomini Giongo $^{2}$ \\ ${ }^{1}$ Goiano Federal Institute, Rio Verde, Brazil \\ ${ }^{2}$ School of Agricultural Engineering, State University of Goiás, Santa Helena de Goias, Brazil \\ Correspondence: Victor Hugo Moraes, Goiano Federal Institute, Rio Verde, Goias, Brazil. Tel: 55-64-99951-0678. \\ E-mail: victor.cm1@hotmail.com
}

Received: October 4, 2018

Accepted: January 25, 2019

Online Published: March 15, 2019

doi:10.5539/jas.v11n4p356

URL: https://doi.org/10.5539/jas.v11n4p356

\begin{abstract}
The measures of precipitation and evapotranspiration can be realized by means of meteorological predictors or by meteorological satellites. Both types have advantages and disadvantages. Emission is one of the most important climatic parameters for a region's socioeconomic and environmental formation, while evapotranspiration is more important for global and local climate mediators. The objective of this work was to analyze the comparative form of the rainfall satellite data through the TRMM and evapotranspiration satellite, by the MODIS satellite, with surface data, that is, of meteorological demarcations, distributed in the State of Goiás, in the years of 2012 and 2013. The monthly measurements were taken in meteorological stations (automatic and conventional), distributed and representative in the State of Goiás. Data collection of the stations was done through the INMET website. The data of the TRMM satellite were obtained from the LAPIG-MAPS platform, developed by the Laboratory of Image Processing and Geoprocessing of the Federal University of Goiás (LAPIG/UFG), for the generation of the quarterly maps for the year 2012 and 2013. The high regression between the data of the surface meteorological stations and the data of TRMM satellite for the year of 2012 and 2013 allows to affirm a high reliability to the orbital data. The evapotranspiration data present low correlation between satellite data (MOD16) and surface stations. Still, this information evidences high potentiality and availability of information in large spatial and temporal scale.
\end{abstract}

Keywords: remote sensing, orbital data, surface data

\section{Introduction}

Monitoring of rainfall by ground stations, such as rain gauges and meteorological radars, and by orbital sensors has been well established for many years, although it still suffers from several limitations (Crow et al., 2011). The spatial representativeness of rainfall stations and the quantitative accuracy of radar and satellite sensors are some limitations. In addition, the use of remote sensing monitoring has advanced considerably in the last two decades through the development of in situ networks (Dorigo et al., 2011) and advanced algorithms (Wagner et al., 2007; Kerr et al., 2012).

Evapotranspiration also determined by remote sensing, when monitored is extensive (Glenn et al., 2010), is a key component of water and energy balance over terrestrial ecosystems (Oki \& Kanae, 2006). As with many other authors, several mathematically related evapotranspiration designs have been developed (Bastiaanssen et al., 1998; Long \& Singh, 2012; Lu \& Zhuang, 2010; Norman et al., 1995; Su, 2002; Yang \& Shang, 2013).

In sum, evapotranspiration consists of two components, soil evaporation and transpiration of the vegetation canopy. As transpiration and photosynthesis are regulated biologically by plants, and transpiration dominates evapotranspiration on vegetated surfaces (Beer et al., 2009; Zang et al., 2009), studies show that the use of remote sensing data can provide (Rawalpha et al., 2008). In the present study, it was found that there were no significant differences between the two groups. Evapotranspiration is also needed to design possible changes in the global hydrological cycle under different climate change scenarios (Alen, 2005; Teuling et al., 2009) and among other applications. 
Rainfall, also linked in a certain way to evapotranspiration, is one of the most important climatological parameters for the socioeconomic and environmental formation of a region (Nobrega et al., 2008). Its obtaining through the use of rain gauges is one of the oldest and most common methods used to measure precipitation. However, due to the cost of operation and maintenance of the rain gauges, they end up being left out and deactivated (Dai et al., 2017). A decline of approximately 50\% in the number of pluviometers occurred in the period 1989-2006 in Europe, South America and Africa (Lorenz \& Kunstmann, 2012; Walsh, 2012). The same situation is not different in Brazil, when one enters in numerous sites to obtain data of precipitation.

In order to overcome the lack of precipitation data along the Earth's surface and to obtain information in difficult to reach sites, the use of remote sensing in precipitation estimates has been widely used after the launch of the Precipitation Measurement Mission Tropical (TRMM) in 1997 (Sahlu et al., 2016). The literature presents numerous publications on the evaluation of satellite precipitation products. A common finding is that the error in satellite precipitation products depends on the region and on the type/magnitude of the precipitation examined (Mei et al., 2014; Aghakouchak et al., 2012; Anagnostou et al., 2010).

The objective of this work was to compare the pluviometric data of the terrestrial and orbital points (through the TRMM satellite), besides elaborating the interpolation of the precipitation and evapotranspiration, of the terrestrial and orbital stations, distributed in the State of Goiás, for the years of 2012 and 2013.

\section{Method}

For this research, the state of Goiás, Brazil, was adopted as a study area. The monthly measurements were met by meteorological stations (automatic and conventional), which represent the entire Goian border. The meteorological station data were obtained through INMET (National Meteorological Institute) for the years 2012 to 2013 .

The orbital precipitation information was obtained through the TRMM satellite, in the LAPIG-MAPS platform, maintained by the Laboratory of Image Processing and Geoprocessing of the Federal University of Goiás (LAPIG/UFG, 2014). The TRMM product used was 3B43, which is a monthly product with low spatial resolution of $0.25^{\circ} \times 0.25^{\circ}$ (approximately $30 \times 30 \mathrm{~km}$ ).

The MODIS sensor data for the accumulated monthly evapotranspiration were obtained from the LAPIG-MAPS platform (LAPIG, 2015). The selection of evapotranspiration data by MODIS was performed according to the temporal availability of each product, on a monthly scale. The product selected for this study was MOD16.

In order to estimate the monthly values of evapotranspiration in the surface stations, information of average temperature, maximum and minimum temperature and solar radiation at the top of the atmosphere were used. After the data acquisition, they were used to determine the evapotranspiration through the Hargreaves method, estimating the monthly accumulation of evapotranspiration by the following equation:

$$
E T_{o}=0.0023 \cdot\left(T_{\text {med }}+17.8\right) \cdot\left(T_{x}-T_{i}\right)^{0.5} \cdot R_{a}
$$

where: Tmed, $\mathrm{Tx}$ and $\mathrm{Ti}$ in ${ }^{\circ} \mathrm{C}$, respectively, represent the mean, maximum and minimum temperatures and $\mathrm{Ra}$ is the solar radiation at the top of the atmosphere $\left(\mathrm{mm} \cdot \mathrm{day}^{-1}\right)$.

The solar radiation at the top of the atmosphere was obtained according to the methodology recommended by Allen et al. (1998).

$$
R a=24.6 / \pi \cdot G_{s c} \cdot d_{R}(H \cdot \operatorname{sen} \theta \cdot \operatorname{sen} \delta+\cos \theta \cdot \cos \delta \cdot \operatorname{sen} \cdot H)
$$

where GSC is the solar constant (mean value of $0.082 \mathrm{MJ} \mathrm{m}^{2} \mathrm{~min}^{-1}$ ); $\mathrm{dr}$ is the inverse of the relative distance from the earth to the sun (vector radius); $\mathrm{H}$ is the hour angle of the sunset (radians); $\theta$ is the local latitude (radians); $\delta$ is the solar declination (radians).

The distance in inverse relation Earth-Sun, $\mathrm{dR}$, and the solar declination, $\delta$, are obtained by:

$$
\begin{gathered}
d R=1+0.033 \cdot \cos (2 \pi / 365) \cdot J \\
\delta=0.409 \cdot \operatorname{sen} \cdot(2 \pi / 365) \cdot J-1.405)
\end{gathered}
$$

where, $\mathrm{J}$ is the Julian day.

After finalizing the collection of all the necessary information to meet the objective of this research, the precipitation data of the surface stations were compared with the pixels of the TRMM images, since they are georeferenced. In the comparison, the Pearson correlation was obtained for the 15 meteorological stations for the year 2012 and 2013, as well as for the rainy and dry seasons in these two dates. Then the second-order polynomial regression was generated for the years of study. 
Table 1. List of weather stations in the state of Goiás

\begin{tabular}{llll}
\hline City & Latitude & Longitude & Altitude $(\mathrm{m})$ \\
\hline Alto Paraiso de Goiás & $-14.133074^{\circ}$ & $-47.523258^{\circ}$ & 1265 \\
Aragarças & $-15.902658^{\circ}$ & $-52.245172^{\circ}$ & 327 \\
Cristalina & $-16.784896^{\circ}$ & $-47.612966^{\circ}$ & 1211 \\
Goianésia & $-15.220199^{\circ}$ & $-48.990107^{\circ}$ & 667 \\
Goiânia & $-16.642841^{\circ}$ & $-49.220222^{\circ}$ & 727 \\
Goiás & $-15.939729^{\circ}$ & $-50.141433^{\circ}$ & 513 \\
Itapaci & $-14.979792^{\circ}$ & $-49.539977^{\circ}$ & 551 \\
Jatai & $-17.923622^{\circ}$ & $-51.717467^{\circ}$ & 670 \\
Luziânia & $-16.260542^{\circ}$ & $-47.966962^{\circ}$ & 1001 \\
Mineiros & $-17.569319^{\circ}$ & $-52.596483^{\circ}$ & 713 \\
Monte Alegre de Goiás & $-13.253520^{\circ}$ & $-46.890326^{\circ}$ & 551 \\
Niquelândia & $-14.469358^{\circ}$ & $-48.485756^{\circ}$ & 664 \\
Paraúna & $-16.962536^{\circ}$ & $-50.425450^{\circ}$ & 679 \\
Posse & $-14.089210^{\circ}$ & $-46.366497^{\circ}$ & 830 \\
Rio Verde & $-17.785303^{\circ}$ & $-50.964869^{\circ}$ & 780 \\
\hline
\end{tabular}

For the interpolation and preparation of the data maps and surface evapotranspiration, both the terrestrial stations and the TRMM and MODIS data, the SURFER version 8.0 graphic program was used. Quarterly maps were created for the year 2012 and 2013. Finally, the geostatistical interpolation method used was the Krigagem method.

\section{Results}

In order to elucidate and evaluate the correlation between the TRMM satellite precipitation data and the terrestrial meteorological stations for the study periods in the state of Goiás, the results are presented in Table 2.

Table 2. Correlation between TRMM satellite precipitation data and meteorological stations in the state of Goias in 2012 and 2013

\begin{tabular}{|c|c|c|c|c|c|c|}
\hline Correlation & 2012 & 2013 & Rainy 2012 & Rainy 2013 & Dry 2012 & Dry 2013 \\
\hline Alto Paraiso de Goiás & 0.9119 & 0.8728 & 0.8731 & 0.8710 & -0.0901 & 0.9243 \\
\hline Aragarças & 0.9737 & 0.9565 & 0.9534 & 0.9432 & 0.8582 & 0.7426 \\
\hline Cristalina & 0.8174 & 0.9781 & 0.7031 & 0.9617 & 0.8427 & 0.9952 \\
\hline Goianésia & 0.8176 & 0.9785 & 0.7044 & 0.9616 & 0.9952 & 0.8664 \\
\hline Goiania & 0.8781 & 0.9615 & 0.6516 & 0.9876 & 0.8253 & 0.9244 \\
\hline Goiás & 0.9679 & 0.9040 & 0.9583 & 0.8796 & 0.9018 & 0.8586 \\
\hline Itapaci & 0.8363 & 0.8093 & 0.6520 & 0.7788 & 0.5855 & 0.7852 \\
\hline Jatai & 0.9396 & 0.9238 & 0.8351 & 0.8027 & 0.9314 & 0.8627 \\
\hline Luziânia & 0.9637 & 0.8767 & 0.9361 & 0.8811 & 0.9561 & 0.9787 \\
\hline Mineiros & 0.8420 & 0.9659 & 0.4781 & 0.9062 & 0.4958 & 0.9348 \\
\hline Monte Alegre de Goiás & 0.8745 & 0.7656 & 0.8402 & 0.7131 & 0.9738 & 0.1347 \\
\hline Niquelandia & 0.9626 & 0.9435 & 0.9242 & 0.8720 & 0.8562 & 0.2688 \\
\hline Parauna & 0.9004 & 0.9456 & 0.8380 & 0.7801 & 0.0726 & 0.8848 \\
\hline Posse & 0.9128 & 0.9290 & 0.8904 & 0.8631 & 0.8635 & 0.9988 \\
\hline Rio verde & 0.9842 & 0.9221 & 0.9701 & 0.8546 & 0.9805 & -0.1310 \\
\hline
\end{tabular}

Subsequently a second-order polynomial regression was obtained for the year 2012 and 2013 (Figure 1). 

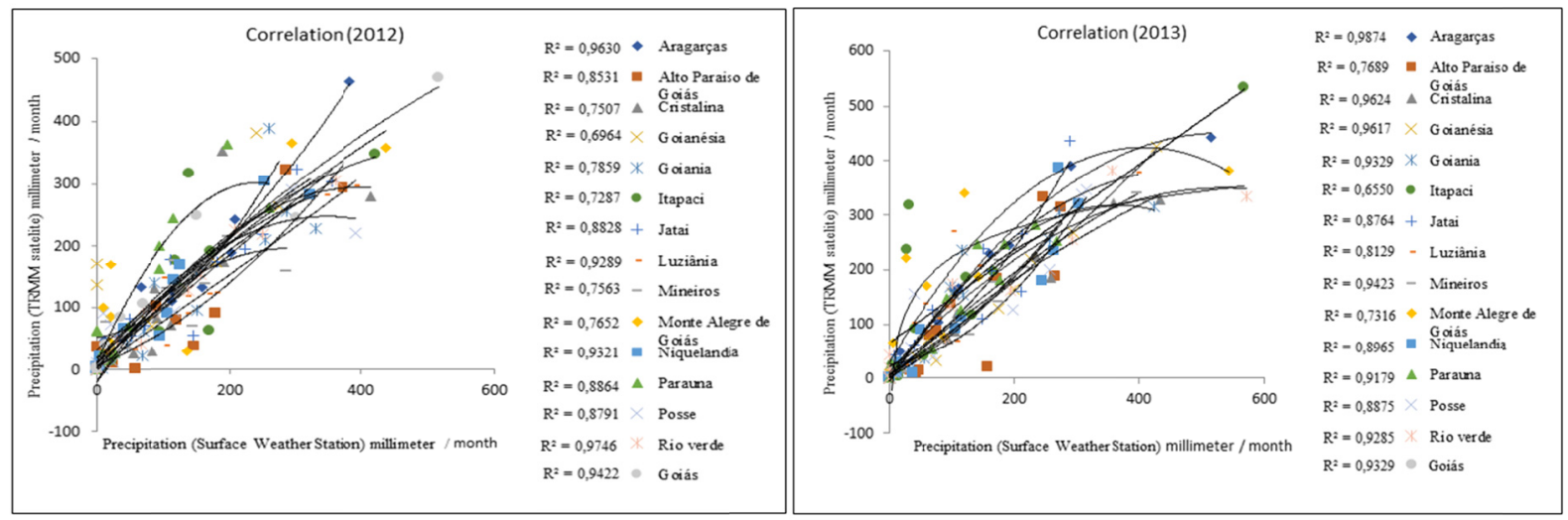

Figure 1. Second-order polynomial regression between TRMM data and surface stations for the period from 2012 to 2013 , in the state of Goiás

The Figures 2 and 3 show the spatialisation precipitation of the surface stations data and orbital data respectively, as well as in figures 4 and 5 the evapotranspiration information.

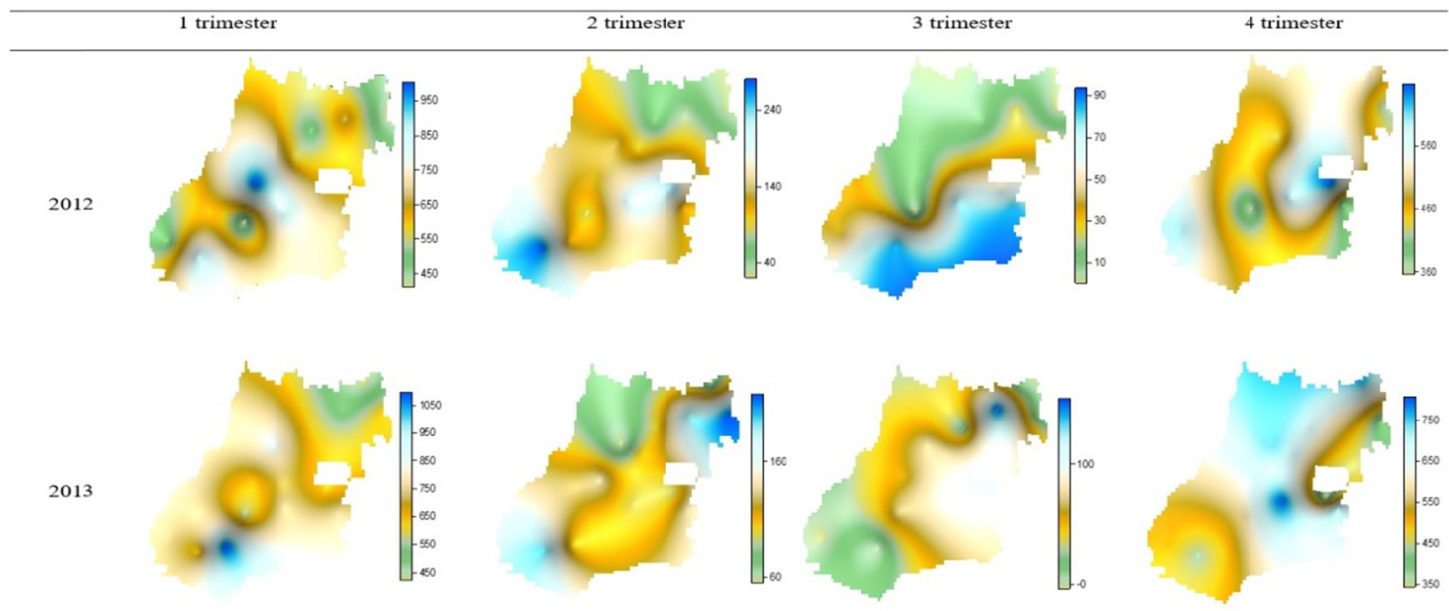

Figure 2. Spatial distribution by interpolation of accumulated values of quarterly precipitation $(\mathrm{mm})$ in the state of Goiás (2012 and 2013) with data from 15 surface meteorological stations

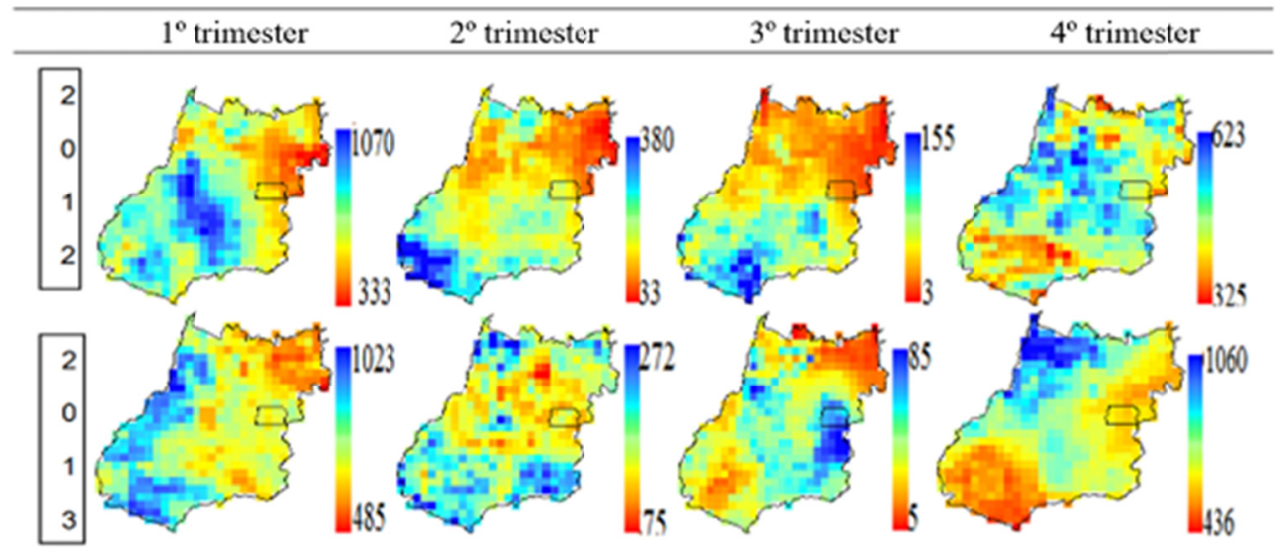

Figure 3. Spatial distribution of precipitation (mm) quarterly in the State of Goiás for the years 2012 and 2013 with TRMM satellite data 


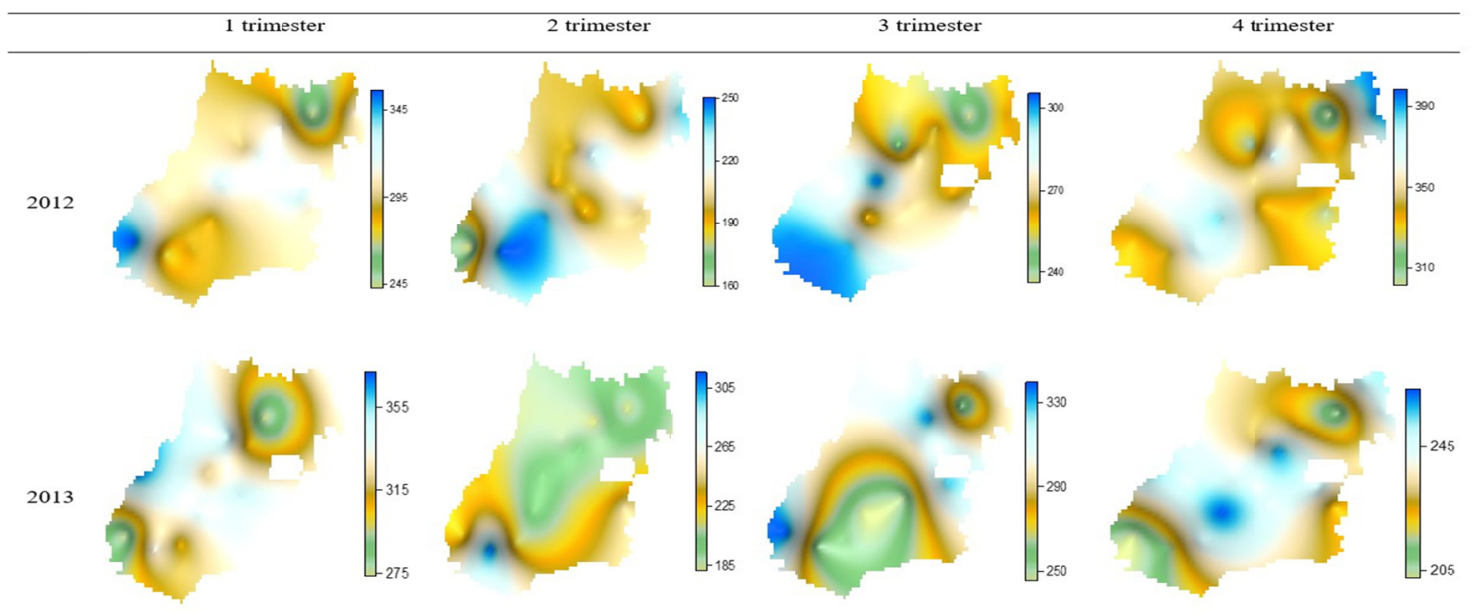

Figure 4. Spatial distribution of quarterly evapotranspiration (mm) in the state of Goiás (2012 and 2013) with data from 15 surface meteorological stations

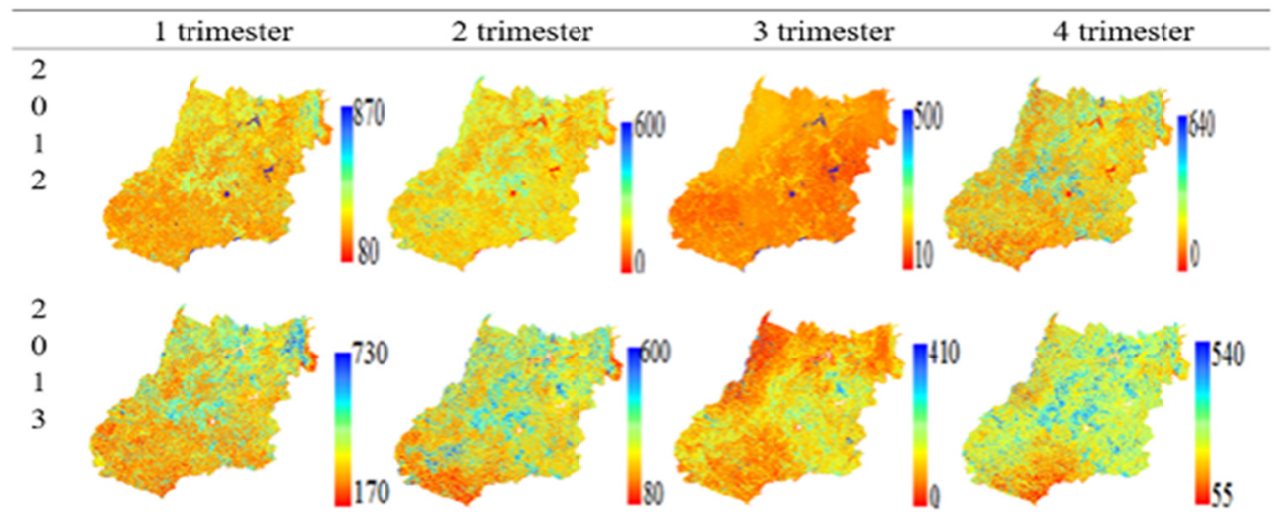

Figure 5. Spatial distribution of evapotranspiration (mm) quarterly in the State of Goiás (2012 and 2013) with data obtained by the product MOD16

\section{Discussion}

For the year 2012, the correlation of pearson evidences that all meteorological stations present a high relation. The stations of Rio Verde and Aragarças presented the highest correlations for this year, that is, smaller differences between the two data sources. Goianésia and Cristalina showed the lowest relationships for the year (Table 2).

However, when a separate analysis is carried out for the dry and rainy months for the year 2012, some changes can occur in the pearson correlation, since Rio Verde and Goiás have the highest relations and Mineiros, Itapacipe and Goiania the lowest in the rainy season. In the dry season, the results showed that the correlations tend to decrease in most stations (Table 2).

In 2013, the highest correlation coefficient was for Cristalina and Goianésia. The lowest correlation obtained was for Monte Alegre de Goiás and Itapacipe. In the rainy season Cristalina and Goianésia still continued among the best results, losing only to Goiania. In drought, in some municipalities the correction tends to fall (Table 2).

The greatest discrepancies between the orbital and terrestrial data are the months corresponding to the dry period, which may be responsible for the lowest correlations. In addition, some errors in the registration of surface stations can also contribute to a low correlation.

The high regression between the data of the surface meteorological stations and the data of satellite for the year of 2012 and 2013 allows to affirm a high reliability to the orbital data. This allows to estimate the precipitation in remote and difficult to reach places, besides supplying the lack of points in the soil, in order to allow to monitor 
the precipitation over the whole terrestrial surface. Some precautions should be taken in times of drought in order to avoid biased estimates (Figure 1).

The quarterly data of precipitation of the surface stations when submitted to interpolation and compared with the maps of the TRMM, present in general, a good relation, except for the seasons of drought (Figures 2 and 3). These data corroborate with those found by Sousa et al. (2013), who also worked with TRMM satellite data for rainfall in the Pantanal region of Mato Grosso.

In the third quarter, lower rainfall volumes were recorded for both the surface station data and the TRMM data, characterizing the dry period in practically the entire state of Goiás. It is at this time that the greatest discrepancy between the orbital data and terrestrial, as can be seen on the maps. These results are similar to those found by Leivas (2009), who also found high similarity between TRMM data and rainfall stations (Figures 2 and 3).

The results reinforce the reliability of precipitation data estimated by satellites, making it an efficient and inexpensive alternative when compared to surface installed instruments, such as meteorological and pluviometric stations, which have higher costs and require constant maintenance and measurement of the data.

In figures 4 and 5, the evapotranspiration data for the terrestrial and orbital stations are recorded. The main differences in these data, which are greater than in the case of rainfall, are due to the generation sources, mainly surface data, which require the use of empirical equations to estimate data that do not exist in many state meteorological stations.

Evapotranspiration is a meteorological variable that can be influenced by different isolated or interrelated factors, such as: local altitude, wind speed and frequency, type of vegetation cover, soil water availability, radiation incidence, among others, what makes it more difficult to estimate and compared with terrestrial and satellite sources.

The estimation of evapotranspiration through the satellite (MOD16) may be related to the way the data is aggregated, or the cogeneration of data of several MODIS products, and can also result in data with errors.

However, although the evapotranspiration data presented a lower correlation between satellite and surface, it is possible to identify the potentiality and availability of information in a large spatial and temporal scale, considering the lack of information and its importance for application in the agricultural area.

Therefore, the TRMM satellite data show a good correlation with the terrestrial stations, which allows, by means of a regression, to estimate the precipitation in places that are difficult to access and that do not have active stations on the ground. However, in times of drought, it is recommended to use orbital information when necessary, since they present larger discrepancies in the estimates.

As for the MODIS satellite evapotranspiration (MOD16), it presented a lower relation than that presented by the precipitation, which may be related to the complexity to obtain it and the various factors that may hinder its attainment. However, in rainy seasons, there is a better similarity between MODIS and terrestrial data, which allows the application of satellite images. However, field checks must be made to confront MODIS information in order not to use evapotranspiration values with high errors.

\section{References}

Allen, R. (2005). The need for high-resolution satellite coverage including thermal (surface temperature) for water resources management. University of Idaho, Kimberly. Retrieved from http://www.idwr.idaho.gov/ gisdata/ET/Landsat\%20issues/thecaseforalandsatthermalband.pdf

Anagnostou, E. N., Maggioni, V., Nikolopoulos, E. I., Meskele, T., Hossain, F., \& Papadopoulos, A. (2010). Benchmarking high-resolution global satellite rainfall products to radar and rain-gauge rainfall estimates. IEEE Transactions on Geoscience and Remote Sensing, 48(4), 1667-1683. https://doi.org/10.1109/ TGRS.2009.2034736

AghaKouchak, A., Mehran, A., Norouzi, H., \& Behrangi, A. (2012). Systematic and random error components in satellite precipitation data sets. Geophysical Research Letters, 39(9). https://doi.org/10.1029/ 2012GL051592

Bastiaanssen, W. G., Menenti, M., Feddes, R. A., \& Holtslag, A. A. M. (1998). A remote sensing surface energy balance algorithm for land (SEBAL). 1. Formulation. Journal of Hydrology, 212, 198-212. https://doi.org/ 10.1016/S0022-1694(98)00253-4 
Crow, W. T., van Den Berg, M. J., Huffman, G. J., \& Pellarin, T. (2011). Correcting rainfall using satellite-based surface soil moisture retrievals: The Soil Moisture Analysis Rainfall Tool (SMART). Water Resources Research, 47(8). https://doi.org/10.1029/2011WR010576

Dai, Q., Bray, M., Zhuo, L., Islam, T., \& Han, D. (2017). A scheme for rain gauge network design based on remotely sensed rainfall measurements. Journal of Hydrometeorology, 18(2), 363-379. https:/doi.org/ 10.1175/JHM-D-16-0136.1

Dorigo, W. A., Wagner, W., Hohensinn, R., Hahn, S., Paulik, C., Xaver, A., ... Robock, A. (2011). The International Soil Moisture Network: A data hosting facility for global in situ soil moisture measurements. Hydrology and Earth System Sciences, 15(5), 1675-1698. https://doi.org/10.5194/hess-15-1675-2011

Glenn, E. P., Nagler, P. L., \& Huete, A. R. (2010). Vegetation index methods for estimating evapotranspiration by remote sensing. Surveys in Geophysics, 31(6), 531-555. https://doi.org/10.1007/s10712-010-9102-2

INMET (Instituto Nacional de Meteorologia). (2014). Estações automáticas. Retrieved from http://www.inmet. gov.br/portal/index.php?r=home/page\&page=rede_estacoes_auto_graf

INMET (Instituto Nacional de Meteorologia). (2015). Estações automáticas. Retrieved from http://www.inmet. gov.br/portal/index.php?r=estacoes/estacoesautomaticas

Kerr, Y. H., Font, J., Martin-Neira, M., \& Mecklenburg, S. (2012). Introduction to the special issue on the ESA's Soil Moisture and Ocean Salinity mission (SMOS)-Instrument performance and first results. IEEE Transactions on Geoscience and Remote Sensing, 50(5), 1351-1353. https://doi.org/10.1109/TGRS.2012. 2191089

LAPIG (Laboratório de Processamento de Imagens e Geoprocessamento). (2014). Retrieved from http://www. lapig.iesa.ufg.br

LAPIG (Laboratório de Processamento de Imagens e Geoprocessamento). (2015). Retrieved from http://maps. lapig.iesa.ufg.br/lapig-maps

Leivas, J. F., Ribeiro, G. G., Souza, M. D., \& Rocha Filho, J. (2009). Análise comparativa entre os dados de precipitação estimados via satélite TRMM e dados observados de superficie em Manaus (Vol. 25, No. 30, pp. 1611-1616). Anais XIV Simpósio Brasileiro de Sensoriamento Remoto, Natal, Brazil.

Long, D., \& Singh, V. P. (2012). A two-source trapezoid model for evapotranspiration (TTME) from satellite imagery. Remote Sensing of Environment, 121, 370-388. https://doi.org/10.1016/j.rse.2012.02.015

Lorenz, C., \& Kunstmann, H. (2012). The hydrological cycle in three state-of-the-art reanalyses: Intercomparison and performance analysis. Journal of Hydrometeorology, 13(5), 1397-1420. https://doi.org/ 10.1175/JHM-D-11-088.1

Lu, X., \& Zhuang, Q. (2010). Evaluating evapotranspiration and water-use efficiency of terrestrial ecosystems in the conterminous United States using MODIS and AmeriFlux data. Remote Sensing of Environment, 114(9), 1924-1939. https://doi.org/10.1016/j.rse.2010.04.001

Mei, Y., Anagnostou, E. N., Nikolopoulos, E. I., \& Borga, M. (2014). Error analysis of satellite precipitation products in mountainous basins. Journal of Hydrometeorology, 15(5), 1778-1793. https://doi.org/ 10.1175/JHM-D-13-0194.1

Nóbrega, R. S., de Souza, Ê. P., \& Galvíncio, J. D. (2008). Análise da estimativa de precipitação do TRMM em uma sub-bacia da Amazônia Ocidental. Revista de Geografia Recife, 25(1), 06-20.

Norman, J. M., Kustas, W. P., \& Humes, K. S. (1995). Source approach for estimating soil and vegetation energy fluxes in observations of directional radiometric surface temperature. Agricultural and Forest Meteorology, 77(3-4), 263-293. https://doi.org/10.1016/0168-1923(95)02265-Y

Oki, T., \& Kanae, S. (2006). Global hydrological cycles and world water resources. Science, 313(5790), 1068-1072. https://doi.org/10.1126/science.1128845

Peng, Y., Gitelson, A. A., \& Sakamoto, T. (2013). Remote estimation of gross primary productivity in crops using MODIS $250 \mathrm{~m}$ data. Remote Sensing of Environment, 128, 186-196. https://doi.org/10.1016/ j.rse.2012.10.005

Rahman, A. F., Sims, D. A., Cordova, V. D., \& El-Masri, B. Z. (2005). Potential of MODIS EVI and surface temperature for directly estimating per-pixel ecosystem C fluxes. Geophysical Research Letters, 32(19). https://doi.org/10.1029/2005GL024127 
$\mathrm{Su}, \mathrm{Z}$. (2002). The Surface Energy Balance System (SEBS) for estimation of turbulent heat fluxes. Hydrology and Earth System Sciences, 6(1), 85-100. https://doi.org/10.5194/hess-6-85-2002

Sims, D. A., Rahman, A. F., Cordova, V. D., El-Masri, B. Z., Baldocchi, D. D., Bolstad, P. V., ... Monson, R. K. (2008). A new model of gross primary productivity for North American ecosystems based solely on the enhanced vegetation index and land surface temperature from MODIS. Remote Sensing of Environment, 112(4), 1633-1646. https://doi.org/10.1016/j.rse.2007.08.004

Sahlu, D., Nikolopoulos, E. I., Moges, S. A., Anagnostou, E. N., \& Hailu, D. (2016). First evaluation of the Day-1 IMERG over the upper Blue Nile basin. Journal of Hydrometeorology, 17(11), 2875-2882. https://doi.org/10.1175/JHM-D-15-0230.1

Sousa, B. S., Arantes, A. E., Cardoso, M. R. D., \& Ferreira, L. G. (2013). Análise comparativa entre dados TRMM e estações pluviométricas no Pantanal brasileiro: Ano base 2006 (pp. 6945-6952). Anais... XVI Simpósio Brasileiro de Sensoriamento Remoto (SBSR), Foz do Iguaçu, PR.

Teuling, A. J., Hirschi, M., Ohmura, A., Wild, M., Reichstein, M., Ciais, P., ... Wohlfahrt, G. (2009). A regional perspective on trends in continental evaporation. Geophysical Research Letters, 36(2). https://doi.org/ 10.1029/2008GL036584

Wagner, W., Bloschl, G., Pampaloni, P., Calvet, J. C., Bizzarri, B., Wigneron, J. P., \& Kerr, Y. (2007). Operational readiness of microwave remote sensing of soil moisture for hydrologic applications. Nordic Hydrology, 38(1), 1-20. https://doi.org/10.2166/nh.2007.029

Walsh, D. (2012). The tricky business of counting rain. NY Times.

Yang, Y., \& Shang, S. (2013). A hybrid dual-source scheme and trapezoid framework-based evapotranspiration model (HTEM) using satellite images: Algorithm and model test. Journal of Geophysical Research: Atmospheres, 118(5), 2284-2300. https://doi.org/10.1002/jgrd.50259

\section{Copyrights}

Copyright for this article is retained by the author(s), with first publication rights granted to the journal.

This is an open-access article distributed under the terms and conditions of the Creative Commons Attribution license (http://creativecommons.org/licenses/by/4.0/). 